\title{
VARIATIONS IN TACTILE SIGNING - THE CASE OF ONE-HANDED SIGNING
}

\author{
Johanna Mesch \\ Stockholm University
}

\begin{abstract}
Tactile sign language is a variety of a national sign language. Tactile signing among persons with deafblindness also includes some minor variations. Early analyses of tactile Swedish Sign Language (e.g. Mesch 1998, 2001) show how interactants use both their hands in tactile communication in two different positions: dialogue position and monologue position. This paper examines the signing variations that partially or functionally blind signers encounter when using one hand to communicate with each other in a conversation dyad in what is one of the most advanced types of sign language communication. In tactile one-handed signing, the signer uses her right hand both for producing and receiving signs, while the addressee uses her left hand not only for receiving but also for producing signs after turn-taking, even though it is the non-dominant hand and, therefore, is not normally used to produce one-handed signs. In this study, conversation analysis was conducted on the discourse of four groups. The results show that some variations depend on the linguistic background of individuals and their everyday communication. A comparative study of a two-handed and a one-handed system is then presented, focusing on issues of simplicity, flexibility, turn-taking, and feedback. Some results showing changes in the sign structures of both communication types are also presented.
\end{abstract}

Keywords: tactile sign language, deafblindness, tactile communication

\section{Introduction}

A deaf-blind person, while gradually losing her/his sight, may go through a process from visual signing to receiving signs with a narrowed visual field and then to tactile signing, first in the monologue position and/or dialogue position, and lastly in one-handed signing. Tactile sign language users see themselves as deaf people who are losing their vision. Most people who prefer to communicate using sign language have type 1 of the Usher Syndrome; thus, 
many deaf-blind persons start out deaf, become fluent signers and then become blind.

It is important to note that the tactile-gestural modality is a different channel than the visual-gestural modality. Deaf-blind signers shift their perception from the visual to the tactile channel, but they still use their hands for the production of signs. In some countries where people use sign language, there is a tactually adapted sign language. But, due to a lack of acceptance and support, this is not true for all countries, and, as such, some deaf-blind signers have not been able to meet and converse together enough to develop conversational patterns in this variety.

Among the languages that have been supportive of the use of sign language among deaf-blind people, including Swedish Sign Language, American Sign Language, and Norwegian Sign Language, research on variation in tactile signing has been conducted in a variety of disciplines, e.g. in reception experiments of tactile signing (Reed et al. 1995); turn-taking and questions (Mesch 1998, 2001); interaction (Raanes 2006, Schwartz 2009); back-channel feedback (Collins and Petronio 1998); questions (Dively and Petronio 2003); adverbial morphemes (Collins 2004); use of indexing (Quinto-Pozos 2002); interpreting (Collins et al. 2004); and signing with impaired vision (Emmorey et al. 2008).

As is the case for other varieties of language use, tactile signing among persons with deaf-blindness is not homogeneous. Here, I am specifically interested in the subject of turn-taking and how it varies with respect to different hand arrangements, looking at monologue and dialogue positions, as in my earlier work (1998, 2001), but also taking perception into consideration. In an interpreted situation, a deaf-blind person receives signs by keeping both of her/his hands on the interpreter's hands, but much information is lost in this manner of interpreting, such as the non-manual signals that appear as facial expressions, which are essential in visual sign languages (Mesch 1994). Thus, it is necessary to have the results from conversation between deaf-blind participants in the analysis of tactile communication in Swedish Sign Language with two hands, both of which are active for receiving and producing the signs in terms of turn-taking and questions (Mesch 1998, 2001).

In this paper, I will present a comparative study of turntaking in four different conversation types in sign language between deaf-blind partners. More specifically, I compare the twohanded and one-handed systems, looking at issues of turn-taking 
and how the hands move during turn changes and how some manual backchanneling signals are used.

\section{Four different conversation types}

The subjects in my study are partially or functionally blind signers with Swedish Sign Language as their primary language. To show the differences within tactile signing for this study, I use recordings of the following four groups: a) a group of three persons with narrowed visual field who converse with each other in Swedish Sign Language; b) a pair of deaf-blind signers who use two hands in monologue position; c) a pair of deaf-blind signers who use two hands in dialogue position; and d) a pair of deaf-blind signers each of whom uses only one hand for receiving signs. The video material from the recordings made of these conversations was partially annotated using the annotation tool ELAN (available at http://www.latmpi.eu/tools/elan). This study provides directions on how to continue doing such research, for example, using larger corpora.

As members of the first group (A), each of the three participants has some sight left and uses sign language for as long as they can and when the lighting is good. Receivers stand or sit one meter away from the signer and focus on the signs within a restricted and raised signing space near the upper chest. The signer has to execute the signs in a somewhat smaller area, near his head (Figure 1). This is called signing with narrowed visual field.

Two-handed conversations where two hands are active in receiving signs may be done in monologue position or dialogue position, as the members of the groups $\mathrm{B}$ and $\mathrm{C}$ do in their conversations. In the context of these interactions, the signers converse sitting opposite each other in four-handed communication and use both their hands for production and perception. In the monologue position, the signer uses her hands in conversation with another deaf-blind partner to produce signs underneath the receiver's hands, allowing the receiver to feel and follow the signer's handshapes and movements in the signing space (Figure 2). The other, more interactive type is the dialogue position, where the signer has two hands in different positions, one under and one on top of the receiver's hands (Figure 3). Both these positions affect the sign structure, mainly in the changing of handshapes and place of articulation (Mesch 2001). 
Here, I introduce a fourth group (D), the members of which use tactile one-handed signing, which is one of the most advanced types of sign language communication. In this variety, the signer uses one or two hands for producing while the addressee receives the signs with only one hand, for example, the right hand (Figure 4). Because the partners sit side by side to communicate using this variety, one signer must use her left hand for producing signs, even though it is the non-dominant hand and thus not usually used to produce one-handed signs. Because the signer usually produces these signs with the dominant hand rather than the non-dominant hand, the movement of the signs is somewhat reduced. Conversely, the receiver may miss some information being conveyed by the use of two-handed signs as she is only touching one of the hands. Users of one-handed signing are usually also accomplished users of interpreting services, as one-handed perception typically develops out of interpreted situations in which the deaf-blind person sits between two interpreters before being able to use it in everyday conversations with other deaf-blind signers.

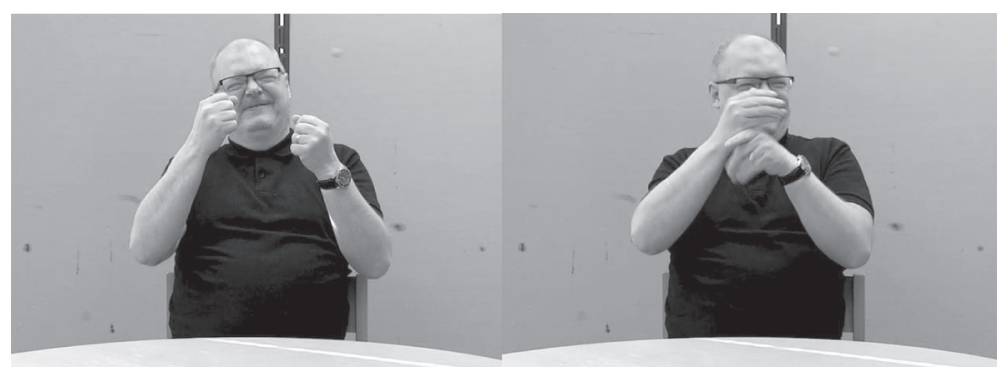

Figure 1. A signer produces two signs, DRIVE-CAR 'drive a car' and CONTINUE 'continue', within a restricted and raised signing space near the upper chest, so an addressee with visual impairment can receive the signs. 


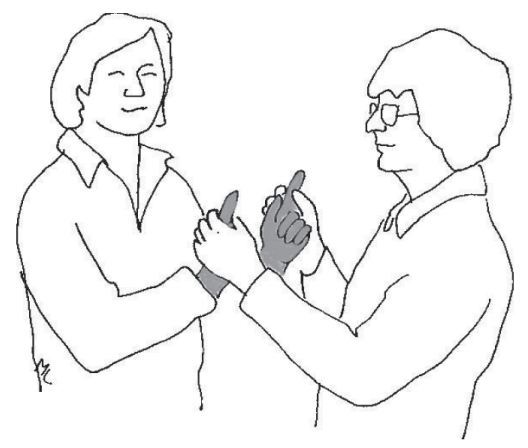

Figure 2. The receiver on the right holds the hands of the signer while she is signing MEET 'meet'. This is called the monologue position. (From Mesch 2004)

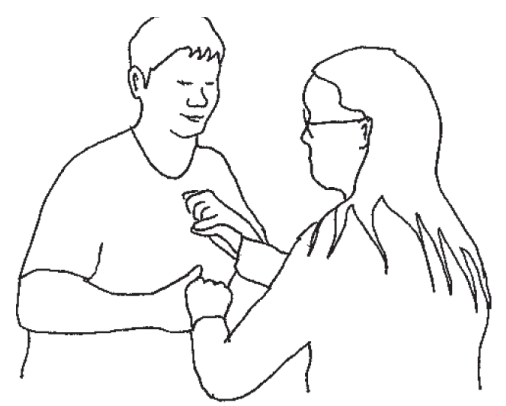

Figure 3. The signer on the left has his right hand under the receiver's hand and his left hand on top of the receiver's other hand. The receiver holds her hand in the same position as the signer's hand position. This is called the dialogue position. (From Mesch 1998)

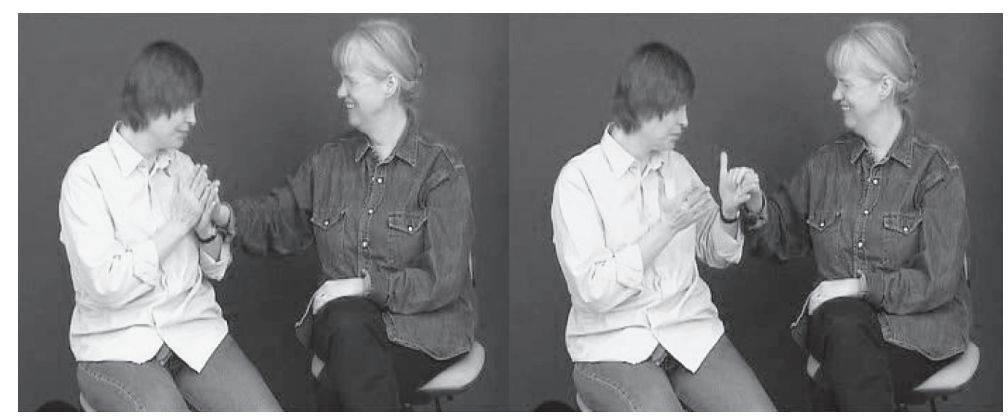

Figure 4. The signer on the left uses both hands for producing the two-handed sign BOOK 'book', and the receiver reads the sign with only one hand. 


\section{Turn-taking}

Tactile sign language differs from visual sign language in many ways, especially regarding the turn-taking system. Eye contact, gaze direction and other non-manual signals of the head are important signals regulating turn-taking in sign language. For example, a signer begins a turn by lifting her hands or makes eye contact to signal that she wants a turn. Backchanneling signals like maintaining eye contact, nodding, headshaking, raising eyebrows or using facial expressions are also non-manual. In tactile conversation, some turn-taking signals are instead made through hand movements. Thus, overlapping is quite common in tactile signing as both partners sign simultaneously at the beginning or the end of turns (Mesch 1998, 2001).

In the case of conversations between persons with narrowed visual field, they sign with both hands within a restricted and raised signing space near the upper chest, and when they are receiving signs they are looking at their hands in that same restricted and raised signing space (see Table 1). They are able to see the visually based turn-taking signals when a signer begins or finishes signing. They do not have their hands touching each other, nor do they change their hand position. Backchanneling signals are made with the face, but minimally.

The persons who communicate in the monologue position use both hands, with the signer producing signs with both hands as usual, but under the receiver's hands with their hands touching. When they change turns, they must move their hands from the producing position under the receiver's hands to the back of the other's hands. The backchanneling signals are manual, such as tapping or applying light pressure to the signer's hand.

Both of the interlocutors' hands also touch each other in the dialogue position with the signer having her right hand under the receiver's left hand and her left hand on the receiver's right hand. The non-dominant hand receives the signs. In this position both partners' hand positions are exactly the same, so they do not need to change their positions after turns. They know that it is time for a turn when the signer lifts her hands and the receiver feels upward or downward movements. The signer can also signal to the receiver for a turn change by moving her non-dominant hand towards the receiver in the last phrase of an utterance/turn. Backchanneling signals such as tapping are also manual but are often done with only the receiver's thumb. 
Persons who use one-handed signing move the hand from the receiving to producing position, as in the monologue position but with only one hand performing both functions. It is interesting to note how the 'one-handed' receiver changes the left hand from the receiving position on the back of the signer's hand to the signing position where the hand can produce signs under the hand of the other person. In this variety, both partners have to select which hand they will use for receiving as well as for producing the signs. They are both fluent signers whose sign language skill compensates for the insufficient input. It is probably one of the most advanced tactile communication systems in that it is more redundant without information from the part of the other hand (for two-handed signs) and also in its turn-taking signals.

See Table 1 concerning hand arrangement in the four conversation types.

Table 1. The use of the hands in four communication types of partially or functionally blind signers.

\begin{tabular}{l|llll}
\hline & $\begin{array}{l}\text { Narrowed } \\
\text { visual field }\end{array}$ & $\begin{array}{l}\text { Monologue } \\
\text { position }\end{array}$ & $\begin{array}{l}\text { Dialogue } \\
\text { position }\end{array}$ & $\begin{array}{l}\text { One-handed } \\
\text { position }\end{array}$ \\
\hline $\begin{array}{l}\text { Hands } \\
\text { producing } \\
\text { signs }\end{array}$ & 2 & 2 & 2 & 2 \\
\hline $\begin{array}{l}\text { Hands } \\
\text { receiving } \\
\text { signs }\end{array}$ & 0 & 2 & 2 & 1 \\
\hline $\begin{array}{l}\text { Hand } \\
\text { touching }\end{array}$ & - & & & \\
\hline $\begin{array}{l}\text { Change of } \\
\text { hand position }\end{array}$ & - & + & + & + \\
\hline $\begin{array}{l}\text { Manual } \\
\text { backchannel }\end{array}$ & - & + & - & + \\
\hline
\end{tabular}




\section{Conclusions}

In this paper, I have shown how a deaf-blind person, while gradually losing her/his sight, may go through a process from visual signing to receive the signs with narrowed visual field, and then to tactile signing. Although some deaf-blind people stay in the monologue/dialogue position because they are comfortable with it as a method of communication, others move on to one-handed signing. Signers may also use different types in various domains and with different people.

Here, I have presented four different conversation types in deaf-blind communication in sign language. These four conversation types have different hand arrangements, but there are both similarities and differences in hand movements during turn changes, overlapping and backchanneling signals. Evidence of change in sign structure is also found among these types.

As shown in this paper, the development of tactile signing is an interesting topic, but many questions need to be answered to understand it more fully. For instance, what is the basic structure of conversation in visual and tactile signing? And how and why has tactile signing developed from the monologue and dialogue position among younger signers? Such questions suggest that the analysis presented here is only a first step in this research direction.

\section{Acknowledgements}

I would like to express my sincere thanks to the subjects who participated in this study. I would also like to thank Lamont Antieau for editing the English version of this manuscript.

\section{Address:}

Johanna Mesch

Department of Linguistics

Sign Language Section

Stockholm University

S-10691 Stockholm

Sweden

E-mail: johanna.mesch@ling.su.se 


\section{References}

Collins, S. (2004) Adverbial morphemes in tactile American Sign Language. Doctoral dissertation. Graduate College of Union Institute and University, Cincinnati.

Collins, S. and K. Petronio (1998) “What happens in tactile ASL?". In C. Lucas, ed. Pinky extension and eye gaze: language use in Deaf communities, 18-37. Washington, DC.: Gallaudet University Press.

Emmorey, K., F. Korpics, and K. Petronio (2008) "The use of visual feedback during signing: evidence from signers with impaired vision". Journal of Deaf Studies and Deaf Education Advance access published online on May 20, 2008. doi:10.1093/deafed/enn020.

Mesch, J. (1994) Dövblindas teckenspråk. En pilotstudie.(Forskning om teckenspråk. 17.) Stockholm: Stockholms universitet, Institutionen för lingvistik.

Mesch, J. (1998) Teckenspråk i taktil form - turtagning och frågor i dövblindas samtal på teckenspråk. Doktorsavhandling. Stockholms universitet, Institutionen för lingvistik, Avdelningen för teckenspråk.

Mesch, J. (2001) Tactile Swedish Sign Language - turn taking and questions in signed conversations of deaf-blind people. (International Studies on Sign Language, 38.) Hamburg: Signum Verlag.

Petronio, K. and V. L. Dively (2006) "YES, \#NO, visibility and variation in ASL and tactile ASL". Sign Language Studies 7, 1, 57-98.

Quintos-Pozos, D. (2002) "Deixis in the visual/gestural and tactile-gestural modalities”. In R. P. Meier, K. Cormier, and D. Quinto-Pozos, eds. Modality and structure in signed and spoken languages, 442-467. Cambridge University Press.

Raanes, E. (2006) Å gripe inntrykk og uttrykk Interaksjon og meningsdanning i døvblindes samtaler: En studie av et utvalg dialoger på taktilt norsk tegnspråk. Norges teknisknaturviten-skapelige universitet, Det historiskfilosofiske fakultet, Institutt for språk- og kommunikasjonsstudier. Doktoravhandlinger ved NTNU, 143.

Reed, C. M., L. A. Delhorne, N. I. Durlach, and S. D. Fischer (1995) "A study of the tactual reception of sign language". Journal of speech and hearing research 38, 2, 477-489.

Schwartz, S. (2009) Stratégies de synchronisation interactionnelle-alternance conversationnelle et rétroaction en cours de discours - chez des locuteurs sourdaveugles pratiquant la Langue des Signes Française tactile. Sciences du Langage. Docteur de l'Úniversite Paris 8. 
Kokkuvõte. Johanna Mesch: Varieerumine taktiilses viiplemises ühe käega viiplemine. Taktiilne viipekeel on rahvusvahelise viipekeel varieteet. Pimedate kurtide seas esineb taktiilse viiplemise puhul samuti väiksemaid varieerumisi. Varasemad rootsi taktiilse viipekeele analüüsid (nt Mesch 1998, 2001) näitavad, kuidas viiplejad kasutavad mõlemat kätt taktiilseks suhtluseks kahes erinevas asendis: dialoogi ja monoloogi asendis. Käesolev artikkel uurib viiplemise varieerumisi, millega pimedad viiplejad kas osaliselt või funktsionaalselt kokku puutuvad, kui nad kasutavad teineteisega suhtlemisel ühte kätt. Niisugune dialoog on kõige rohkem arenenud viiplemise tüüp. Taktiilses ühe käega viiplemises kasutab viipleja oma paremat kätt nii viibete moodustamiseks kui ka vastuvõtuks, samas kui adressaat kasutab oma vasakut kätt samadel eesmärkidel pärast vooruvahetust. Siiski on vasak käsi mittedominantne, seepärast ei kasutata seda üldjuhul viibete moodustamisel ühe käega. Käesolevas uurimuses viidi läbi vestlusanalüüs neljas rühmas. Tulemused näitavad, et osa varieerumisi sõltub üksikisikute keelelisest taustast ja nende igapäevasuhtlusest. Seejärel esitatakse kahe ja ühe käega viiplemise süsteemi võrdlev uurimus, keskendudes lihtsuse, paindlikkuse, vooruvahetuse ja tagasiside küsimustele. Esitatakse ka mõned tulemused, mis näitavad muutusi mõlema suhtlustüübi viibete struktuuris.

Märksõnad: taktiilne viipekeel, pimedate kurtus, taktiilne suhtlemine 